\title{
The Investigation of the Competitiveness of Tourism Industry in Romania
}

\author{
Xiaowen $\mathrm{Wu}$ \\ Beijing Jiaotong University \\ BJTU \\ Beijing China \\ 355798896@qq.com
}

\author{
Xuemeng Guo \\ Beijing Jiaotong University \\ BJTU \\ Beijing China \\ xmguo@bjtu.edu.cn
}

\begin{abstract}
Romania is a raising tourism destination in $\mathrm{EU}$ in recent years. For the purpose of providing suggestions and reminding for the government of Romania, this article is a report which uses secondary data with multi-dimension description to discussion and analyze about the manifestations and existing problems of competitiveness including the aspects of rural tourism, infrastructure \& facilities, environment and political corruption in Romanian tourism development. Also, this report will discuss some specific problems by combing them with literature and theory including if the transport, telecoms, hotel infrastructure needs to be improved to support the development of tourism and meets the needs of tourists; does rural tourism is an important tool to make contribution to Romanian tourism; can the harm of mining industry be a barrier to Romanian tourism industry.
\end{abstract}

Keywords-Competitiveness; tourism destinations; Rural tourism; Infrastructure; Environment; Political corruption

\section{INTRODUCTION}

Romania, which is one of the largest country of the EU(European Union), locates at the crossing of Central and Southeastern Europe bordering on the black sea, and the plains with hills in the eastern region are rolling, fertile and this is the mainly terrain of Romania with the Carpathian mountain in the north and west in the center of the country ranges running. However, it is presented about 90 percent of total area of Romania are rural areas where own 47.3 percent of the whole population with average amount of 800 people per Romanian village (see Appendix 2). The beautiful natural landscapes and the rich history of Romania help the development of tourism. Thus, tourism, the second largest component of the services sector following commerce, becomes one of the sectors that is developing the most dynamic and fastest and offers a huge developing potential for Romania.

Tourism, one of the most important sectors of world's economy, involves in its development a series of interfacing services, such as transport systems, informational and communication technologies, recreation and relaxation alternatives. Tourism development in Romania is not sufficient compared with the global and European Union level. According to a report from World Travel and Tourism Council (WTTC), tourism absorbed $7.3 \%$ of the total capital investments from Romania, compared with the average of the EU of $8.9 \%$ and the global level of $9.4 \%$. Tourism in Romania could increase GIP with up to $4 \%$ which, currently, represents only $2 \%$ of the GIP and also falls behind other European countries. The quality of life in rural areas of Romania is universally not rich. Theory and specific problems have not been linked or fully deliberated in previous study to analyze the competitiveness of tourism in Romania. Previous studies are mainly focused on one particular aspect on Romania's tourism development; instead, this report comes with multi-dimension description and discussion, aiming to give a comprehensive scene about the problems that reject the Romania's tourism competitiveness. The report can help understand development of tourism and the manifestation of tourism competitiveness in Romania.

\section{LITERATURE REVIEW}

\section{A. The Concept of Competitiveness}

The competitiveness of tourism can also be described with the elements that make a destination competitive as defined by Ritchie and Crouch (2003), "...its ability to increase tourism expenditure, to increasingly attract visitors while providing them with satisfying memorable experiences and to do so in a profitable way, while enhancing the wellbeing of destination residents and preserving the natural capital of the destination for future generations". Competitiveness has become a central focused point of tourism policy. In the circumstance of intense competition and increasingly tourism activities, tourism policy aims at improving competitiveness by establishing a legal system to administrate and enhance quality and efficiency of the tourism activities and to protect tourism resources from wasting and destroying.

\section{B. Rural Tourism}

However, according to Lewis, James B. (1998) et.al one of the most popular issues is that rural community use tourism as a tool for development. Roselyne N. Okech(2008) said that "it is thought that rural tourism can revitalize the conventional concepts and views on tourism, and bring in a new dimension in the sustainable development of tourism." Rajeev Kumar (2008) used to view rural tourism as a subset of tourism which consists of so many ranging aspects including farm or agricultural tourism, cultural tourism, nature tourism, adventure tourism, and eco-tourism. "Situated at the cross road of many important European transport corridors that connect the south-east with west and north, Romania had major problems regarding road 
infrastructure and major investments are taking place in order to improve the situation."(Lavinia Oana Peter, 2008)

\section{Infrastructure and Facilities}

Prideaux (2000) points that public infrastructure is important to the capacity of establishing high quality tourism destinations in a country. In Go and Govers's (2010) study, it highlights the key factors for measuring a tourism destination's competitive side compared with other destinations including infrastructure, carrying capacity, quality of service, purchasing power, location image, attractiveness points, climate and environment. In terms of transport infrastructure, Prideaux (2000) proposes the transport system related to tourism as "the operation of, and interaction between, transport modes, ways and terminals that support tourists into and out of destinations and also the provision of transport services within the destination." In terms of hotel industry, Mace (1995) and Litteljohn (1997) has mentioned that hotel industry is usually regarded as one of the most global industry in the tourism or service field. On the other hand, hotel industry will also benefit from tourism, thereby it may face fierce competition.

\section{Environment}

Tourism development is based on satisfaction and safety from tourists and protection of the nature, which leads to the awareness to maintain a balance among economy, ecology and environment in tourism (Vujic, 2005). Tourism is closely linked to environment and the climate. In their selection of the vacation destination, contemporary tourists imply the existence of primary elements which include (Golja, 2009): ecologically preserved environment, accommodation/catering offer, various activities, and the atmosphere. Thus, it is fair to say that contemporary tourists are ecologically aware and especially interested in experiencing the atmosphere and becoming familiar with the identity of the destination.

\section{E. Corruption of Politics}

"Corruption the abusive use of the public power for the purpose of obtaining, for oneself or for others, undeserved benefits" (Cristina, 2010). Măndescu (2011) proposed that political corruption is concentrated in the manifestation of the senior state officials, political parties and political leaders. In Romania, corruption exists widely in many aspects of activities such as politics wich contains the use of power and privilege by politicians for their private purposes (Măndescu, 2011).

\section{METHODOLOGY}

This research analyzes the competitiveness of Romania by collecting data. The Destination Competitiveness \& Sustainability Model (Ritchie and Crouch, 2003, see Appendix 1) is used to make an assessment of the competitiveness of Romania. Briefly, the competitiveness can be classified into comparative advantage (resource endowments) and competitive advantage (resource deployment). The comparative strengths that initially results from the resource endowments have been associated by nature and the economic and historical development of the destination. Ritchie \& Crouch's (2003) model also concerns about the macro and micro environment.

The model consists of five dimensions, namely qualifying \& amplifying determinants (e.g. safety/security), destination policy, planning \& development (e.g. Monitoring $\&$ evaluation), destination management (e.g. quality of service/experience), core resources \& attractors (e.g. culture $\&$ history ) and supporting factors $\&$ resources. This research focuses on the supporting factors \& resources, including infrastructure (insufficient infrasturcture), facilitating resources (rural tourism and environment deterioration ) and political issue (corruption), since they are the very basis and provide a foundation upon a success tourism industry.

\section{DISCUSSION}

\section{A. Side Effect of Insufficient Infrastructure}

Infrastructure plays an important part in the support of a country's economic growth and social development (Hardwicke, 2005). If the infrastructure is not sufficient, the operating cost of tourism development and investment capital will be added as a burden and thus reducing the competitiveness of tourism. Development of tourism cannot live without the support of optimized construct of infrastructure and facilities.

1) Argument: The transport in Romania is insufficient to support tourism development: As Prideaux (2000) mentioned that transport is a prerequisite for developing a tourism destination. Transport development can strengthen interregional and urban-rural connection to guarantee the flexibility and continuous flow of goods or services. Advanced infrastructure of transport, especially the land transportation is likely contribute to the decreasing in the cost of transport because it can reduce wear and tear, fuel cost and save time, thereby the quality of transportation infrastructure can influence the quality of tourists' experience. However, transport is not that impeccable and problems still exist widely in Romanian tourism development. The transport networks cannot fully satisfy business and social demands. Recently, the cost of transport owned by foreign businesses or companies is high. Romania is one of the biggest latent beneficiaries with the help of the plans provided by a cooperation of international banks to load Leu2.4billion for 27 infrastructure aid projects in Eastern Europe in the next several years but the improvement and consequences will come slowly. To optimize the transport system, based upon (Firth, 1999) multiple stakeholders such as government and industries should make good cooperation and make huge investment to achieve corporate objectives. It is necessary to maintain existing transportation facilities and to extend their use. Moreover, making sure the quality of transport infrastructure is important when facing the increasing burden of tourism growth by continuously upgrading transport facilities and service levels. It is also noteworthy 
to strictly enforce environmental protection measures to reduce damage of nature or historical sites and when building transport facilities.

2) Argument: The telecoms and hotel industry in Romania fails to meet tourists' need: Telecoms network is a vital tool for the connection of tourists and tourism destinations to achieve economic and social benefits, especially the use of broadband or high speed internet. However, telecoms industry in Romania has a weak foundation and is constraint by low rate of PC occupancy, low proportion of phones coverage and low rate of use of Internet but expensive charges of phone and Internet. Romanian retail industry is still dominated by small operation and family-run enterprise but is undergoing rapid development of modernization. The quality of the telecoms infrastructure needs to be enhanced continuously based on the liberalization of the fixed-line infrastructure network. The government should make clear and simple policies and laws for interconnecting all telecoms forms to optimize telecoms networks. Personal enterprises should cooperate with government investing their respective resources to establish telecoms network. More specifically, main telephone stations and public calling office should be constructed, and telephone density should be also increased and widen coverage to match the developmental standard of multiple regions and the needs of tourism development. More importantly, broadband and high speed Internet should be used to accelerate exchange of information and enhance the interaction between different stakeholders of tourism industry. Government should help to invest in popularizing the broadband and online communication for tourism information exchange. Additionally, the government should cease unnecessary fees and tax and shift the fund to relatively undeveloped part of telecoms.

\section{B. Issues of Rural Tourism}

Nowadays, rural tourism has become a very popular and important topic around the worlds, for even those developed countries have rural areas and rural tourism has been a keytool to perfect economic structure within this concept. It has been realized that society based tourism can play a fundamental role in poverty alleviation in countries like Romania (Roselyne N. Okech, 2008).This part takes Maramures in Romania as an example where was improved slowly since 1996. Due to the neglected infrastructure, the lack of interest of local and central authorities, developing rural tourism in the areas like Maramures in Romania is becoming more and more serious and need for accelerating economic growth.

1) Argument: Rural community in Romania can be used as a tool for development: According to Lewis, James B. (1998) et.al one of the most popular issues is that rural community use tourism as a tool for development. Following previous statements, the first step is to regards rural tourism as a plural and comprehensive activity. Then, we should try to examine the destinations' attractions for tourists of rural area, (here use Maramures as example) According to Negi (1990) attractions in rural areas includes enjoyment of rural scenery, the desire for open space, quiet and peace of mind. Maramures has a unique individuality that the incomparable beauty of its landscape, pristine lake, lush green countryside and the picturesque heavy forested mountains. When using tourism as a tool for development, we should also consider about the complexity of local development troubles, where any activities may have close link to circumstance under practice. After that, the integration of all the facets will be one of the most important drivers, which means the integrated tourism in rural area. "The integrated tourism means that this method will try to integrate and operated, the potential for development of all social, economic and environmental factors."(Adelaida Cristina, 2011) In this respect, we consider the cooperation and networking possibilities, and add continuity. In order to keep the revenues from rural tourism in the region, integrated tourism can be seen as a special method of working, especially in poorer regions. In this field, the combination of modern and specialized production, the protection of monuments and vast cultural heritage of wooden objects, with a specific tour shows an economic and cultural opportunity in Maramures and other regions in Romania.

2) Argument: The poor transport infrastructure leads to poor accessibility: In a sense the key attractions for the visitors and the revenue are village landscape, community, wildlife, natural legacy and cultural life. As mentioned above, though rural areas in Romania really have the tourism potential, they have weakness in accessibility. "Situated at the cross road of many important European transport corridors that connect the south-east with west and north, Romania had major problems regarding road infrastructure and major investments are taking place in order to improve the situation."(Lavinia Oana Peter, 2008) This problem is also obvious and serious in Maramures. The definition of rural tourism is "Any form of tourism that showcases the rural life, art, culture and heritage at rural locations, thereby benefiting the local community economically and socially as well as enabling interaction between the tourists and the locals for a more enriching tourism experience can be termed as rural tourism" (Aref, F., 2009) We should see that Maramures is a place that fit for the concept of rural tourism, but Maramures is totally enclosed by mountains with a thin opening at Khus, so it is not easily accessible. As a result, tourists may choose somewhere else for they just want to experience new things and having fun. The air transport in Maramures is not welldeveloped after joining European Union though the government knows the importance for changing and developing the airports infrastructure. The lack of motorways leads to the decrease in tourist's demand for no one like to waste a long period of time on the way. There are many other rural region like Maramures in Romania that has the same touchy issue in transportation. As a member of 
European Community, Romania has been benefited from the accession funds, which are larger than the pre-accession funds. The total amount allocated for Romania for Structural and Cohesion Funds is Euro 19,668 billion during 20072013. Allocations for rural development and agriculture are estimated at Euro 7.1 billion for Rural Development. Romania government could make full use of the funds and allocate larger percentage of the whole allocations for sustainable developing transportation system (rail, roads, bicycle lanes, regional airports) in rural areas. It is needed to build more airports, especially international airports, improve territorial accessibility and better meet the mobility needs of the citizens, especially in rural areas.

\section{Mining industry affecting the environment}

1) Argument: The harm brought by mining industry in Romania decrease the quality of tourism competitiveness: One among the tourism theories states that in general tourism is comparatively dependent upon a healthy environment (Sadler 1988). This leads to an argument as tourism should associate itself strongly with the concepts such as ecotourism and sustainable development. General environmental factors may attract tourists to some degree, however, what keeps the coming of tourists is more likely to be infrastructure, price and marketing.Here in Romania, where rural tourism and natural tourism is of great significance, it is vulnerable to environment deterioration. The natural environment in Romania is challenged especially with the development of mining industry. The ores in Romania are diversified and dispersive in territory, which creates a serious barrier as waste run through a huge part of the whole country, diverse technological treatment processes as well as the widespread of polluting waste (Monica and Grigore, 2002).

Mining dumps have a different and special structure. As a result, some negative effects do exist in the environment. Some outstanding negative effects on environment of mining industry are:

- Increased land occupation of mining dumps during the exploitation and development;

- Water pollution- residual and polluted water from the mining industry, because of the chemical emissions, contribute to general water run-off which affects both animals and plants.

- Air pollution- the underground mining activities result in air pollution. The evacuated air generates from mine aeration due to a multiple effect generated by condensation and other industrial procedure in the underground activity.

- Unexpected hydrographic condition- occupation of various surfaces, affecting the hydrographic condition and natural feature.

\section{Political Corruption of Romania}

Although according to the model, the political issue is among the basis, in Romania the problem is quite outstanding and it seems that political corruption is the most serious problem that has significantly affected the healthy development of tourism.

1) Argument: The weekness of political corruption has become a main barrier to the healthy tourism development referring to tax policy, government efficiency and execution of the law: Romania is regarded as the most corrupt country in EU. The most corrupt parts in the country are political parties, parliament and justice (Global Corruption Barometer, 2007). Bureaucracy in Romania is not developed and with excessive red tape which is a problem for the development of tourism. Although the anti-corruption strategy was adopted to help Romania win the EU membership bid, the progress of anti-corruption has slowed and been an obstacle of the development of the economic growth.

In terms of tax policy, highly frequent changes and nonuniform enforcement of tax policy are main risks in the field of political support for the development of tourism and economic growth. Moreover, a complex tax system for personal tax which required five rates between $18 \%$ and $40 \%$ and a $25 \%$ rates on company income tax are out of fashion and needs to be reformed to optimize the tax environment of Romania. In addition, the government set up the tax policy of turnover for the SMEs which was not fit for their developmental trend because SMEs had low turnover and many of them were avoiding paying taxes. Thus, the reform of income tax is necessary to stabilize the frequent change of tax policies and the enforcement of tax laws should be powerful to make sure about the tax imposing.

Moreover, although the efficiency of the government has improved, the progress is still too slow to enhance the effectiveness of government. The shortage of the public administration blocks the government effectiveness. Furthermore, the systems of the execution of law are weak, especially in commercial law. The reform of judicial institution which is used to strength the independence of the judicature is damaged by administrative obstructing. Therefore, the reform of legal system is benefit to guarantee the independence, efficiency of legislation. In addition, public purchase is lack of transparency and the new form of government procurement needs to be executed.

\section{RECOMMENDATION}

As rural community want to use tourism as a tool for development, we should suggest tourism as complex plurality of multi-faced activities and a subset of tourism that consists of ranging aspects. We should also consider about the complexity of local areas, and examine the attractions and then to integrate and consider the cooperation and networking possibilities of all these ranging aspects that may have influence on rural tourism in order to keep the revenues from rural region. As a member of European Community, Romania has been benefited from the accession funds which allocate the rural development. Romania government could make full use of the funds for sustainable developing transportation system (rail, roads, bicycle lanes, regional 
airports) in rural areas. To build more airports, especially international airports, improve territorial accessibility and better meet the mobility needs of the citizens are practicable, especially in rural areas. To develop cultural tourism is also a way that can benefit huge and the expected value so that the tourism offers won't be old, uncompetitive and stereotype any more.

Infrastructure plays an important role to support a country's economy growth and social development (Hardwicke, 2005 \& Jonsson, 2005). Therefore, issues of infrastructure should be paid sufficient attention and coped by both government and tourism managers. In terms of transport problems, to maintain existing transportation facilities and to extend their use is an objective and path to develop transport facilities. In the aspect of telecoms, government and private operators should make cooperation in related policy making and executing to optimize telecoms networks. Refer to hotel industry, government should adjust policies and laws to rule and guide the direction of development of hotel industry such as approving special areas or superior location for hotel buildings, and provide opportunities of hotel to host non-tourism activities including political conference or cultural exchange meeting, etc in off season of tourism. Hotel managers should also have clearly knowledge about the need and requirement of customers, thus the improvement of service quality is significant in the hotel management strategy. Moreover, hotel staff should be well trained in order to provide attractive image to the customers and create brand loyalty to attract more frequent tourists to gain competitiveness in the global market.and come through establishing customer relationship management(CRM).
In terms of political corruption, to repair the damage that political corruption did to Romania, public servants should take sufficient responsible and guarantee the duty of their jobs. It is necessary to optimize the system of selection, training and regular evaluation of government servants according to professional objectives and well-monitored mechanism. Moreover, it is important for citizens to know the reasons, process and results of the corruption and to preserve the citizens' rights when facing corruption. Refer to tax policy, the reform of income tax is necessary to stabilize the frequent change of tax policies and the enforcement of tax laws should be powerful to make sure about the tax imposing. Moreover, to simplify the excessive ordinances and enhance government servants' capacity of implement are good ways to strength the government effectiveness. Meanwhile, the reform of legal system is benefit to guarantee the independence, efficiency of legislation. In addition, public purchase is lack of transparency and the new form of government procurement needs to be executed.

Environment protect in today's Romania is a major problem. As discussed that the mining industry in Romania do have a serious negative influence on attracting tourists' interest, sound policy and regulation should be taken into consideration. Much of the neglect of a healthy tourism results from the private ownership and control of many tourist destination areas and lack of government's and public sectors' involvement. Pollution punishment and restriction of waste level, for example, as well as other make-up methods are of significance. It calls for a significant laws and environmental systems of managing natural resources including air, water, soil, biodiversity as well as other representative samples of natural resources.

\section{APPENDIX}

\section{Appendix 1}

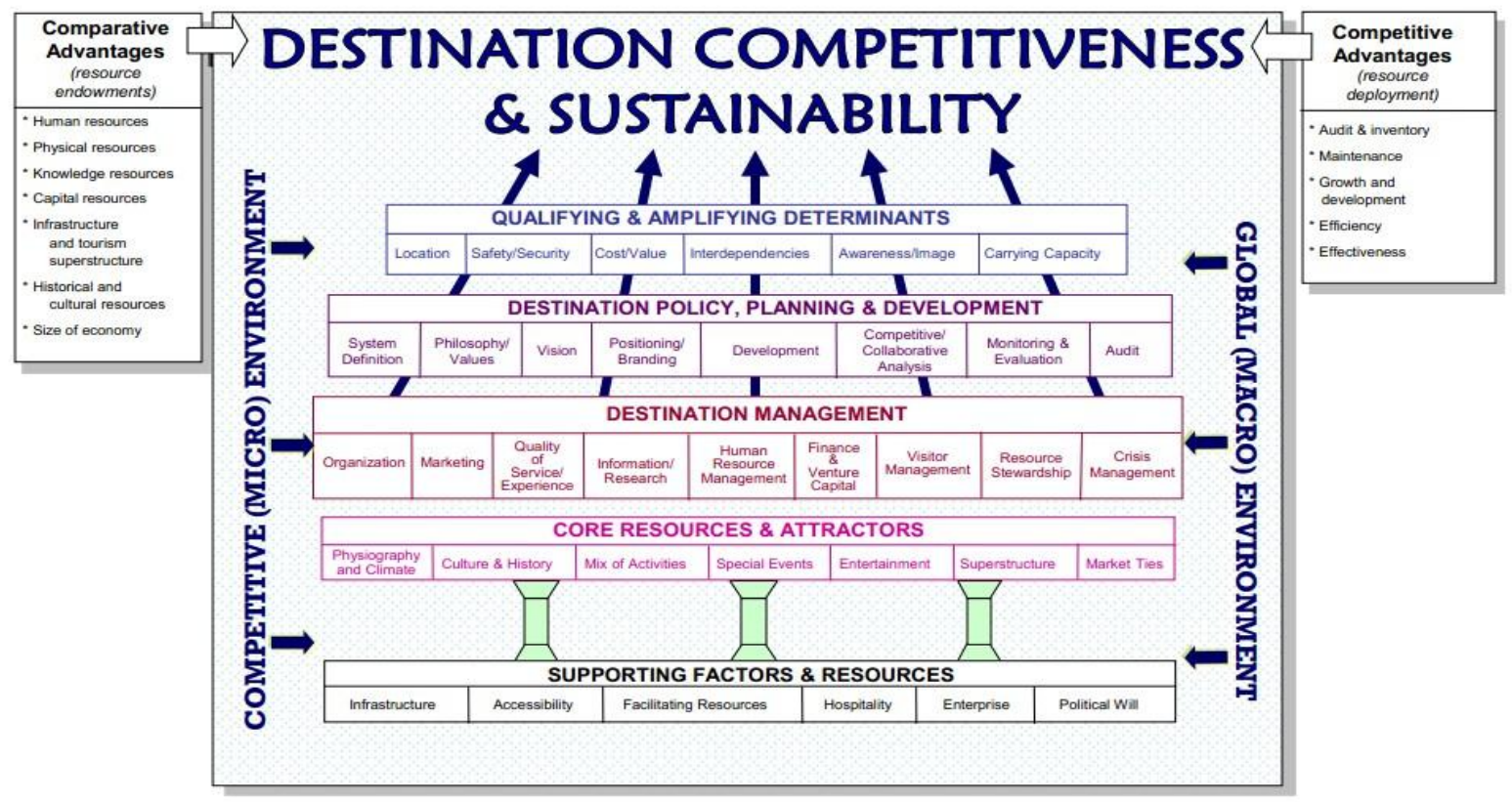




\section{Appendix 2}

\begin{tabular}{|c|c|c|c|c|c|c|c|}
\hline Rank & City name & County & Pop. & Rank & City name & County & Pop. \\
\hline 1 & Bucharest & Bucharest & $1,677,985$ & 11 & Brăila & Brăila & 168,389 \\
\hline 2 & C1uj-Napoca & Cluj & 309,136 & 12 & Piteşti & Argeß & 148,264 \\
\hline 3 & Timişoara & Timiş & 303,708 & 13 & Arad & Arad & 147,992 \\
\hline 4 & Iași & Iaşi & 263,410 & 14 & Sibiu & Sibiu & 137,026 \\
\hline 5 & Constanța & Constanţa & 254,693 & 15 & Bacău & Bacău & 133,460 \\
\hline 6 & Craiova & Dolj & 243,765 & 16 & Târgu Mureș & Yures & 127,849 \\
\hline 7 & Ga1ați & Galați & 231,204 & 17 & Baia Mare & Yaramures & 114,925 \\
\hline 8 & Braşov & Braşov & 227,961 & 18 & Buzău & Buzău & 108,384 \\
\hline 9 & P1oiești & Prahova & 197,542 & 19 & Botoșani & Botoşani & 100,899 \\
\hline 10 & Oradea & Bihor & 183,123 & 20 & Satu Mare & Satu Mare & 94,948 \\
\hline
\end{tabular}

\begin{tabular}{|c|c|c|c|}
\hline Development region $\widehat{*}$ & Area $\left(\mathrm{km}^{2}\right) \div$ & Population (2004) & 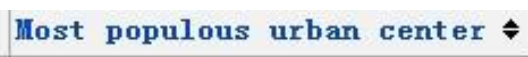 \\
\hline Northeast & 36,850 & $3,743,532$ & Iași $(402,786)$ \\
\hline West & 32,028 & $1,958,648$ & Timișoara $(367,347)$ \\
\hline Northwest & 34,159 & $2,749,958$ & Cluj-Napoca $(379,705)$ \\
\hline Center & 34,082 & $2,540,480$ & Brașov $(402,041)$ \\
\hline Southeast & 35,762 & $2,865,024$ & Constanța $(446,000)$ \\
\hline South & 34,489 & $3,379,406$ & Ploiești $(300,358)$ \\
\hline Bucharest-Ilf ov & 1,811 & $2,492,495$ & Bucharest $(2,192,372)$ \\
\hline Southwest & 29,212 & $2,334,453$ & Craiova $(333,834)$ \\
\hline Romania & 238,391 & $\vee 22,063,996$ & Bucharest $(2,192,372)$ \\
\hline
\end{tabular}

\section{REFERENCES}

[1] Adelaida Cristina, Integrated tourism concept- a contribution to regional development in the country maramures, 2011.

[2] Aref, F., Community capacity building in tourism development in local communities of Shiraz, Iran. Putra, UPM, Selangor, Malaysia, 2009

[3] Cristina. Z., (2010). Corruption in service providing companies, in the context of Romania's integration in the European Union. Academy of Economic Studies Bucharest, Management, 2011.

[4] Fariborz Aref \& Sarjit S Gill, (2009). Rural Tourism Development through Rural Cooperatives. Nature and Science, 2009; 7(10).

[5] Govers, (2010). 2010 International Place Branding Yearbook: Place Branding in the New Age of Innovation. Palgrave Macmillan, 2010.

[6] Howes, R. and Robinson, H. (2005), Infrastructure for the Built Environment: Global Procurement Strategies, ButterworthHeinemann, London.

[7] Jonsson, D.K. (2005), "The nature of infrasystem services", Journal of Infrastructure Systems, Vol. 11 No. 1, pp. 2-8.

[8] Măndescu. I. (2011). Tax evasion and corruption in the development of Romania. Bulletin of the Transilvania University of Braşov. Vol. 4 (53). No. 2 - 2011. Series V: Economic Sciences.

[9] Mirela Mazilu(2011), Romania- an Attractive Tourist Market after the World Economic Crisis. Faculty of Economics and Business Administration University of Craiova -University Centre of Drobeta
Turnu Severin Str. Calugareni 1, Drobeta Turnu Severin Issue 2, Volume 5, 2011.

[10] National Strategic Reference Framework - Romania 2007-2013.

[11] North altantic treaty organization (report). NATO. http://www.nato.int/invitees2004/romania/glance.htm. Retrieved 2008-08-31.

[12] "Prezentarea generală a rețelei de drumuri" (in Romanian). cnadnr.ro. Retrieved 2009-09-07.

[13] Rajeev Kumar: Service quality in rural tourism: a prescriptive approach conference on tourism in India- Challenges ahead, May 2008

[14] Research and Markets, Business Wire: Romania Tourism Report Q3 2011 - Resident Departures Abroad Fell an Annual 7\% in 2010, Following an Even Larger Fall Of 10\% in the Previous Year.

[15] Romania.2 (48 ed.) London and New York: routledge. 2007. pp. $3734-3759$.

[16] Roselyne N. Okech, (2008). Promoting rural tourism in Kenya and Romania. No.8, 2008.

[17] Roxana Nanu, Ramona Gruescu, R. Buziernescu, European experience in the field of rural tourism, 2008.

[18] "Sat - Enciclopedia României - prima enciclopedie online despre România" (in Romanian). Enciclopediaromaniei.ro. 2011-05-07. Retrieved 2011-08-29.

[19] UN News Centre (2009), "High-speed internet gap between rich and poor widening, UN official warns", 12 November 2009, available at: www.un.org/apps/news/story.asp? NewsID ?32942. 
[20] Van der Mandele, M., Walker, W. and Bexelius, S. (2006), "Policy development for infrastructure networks: concepts and ideas", Journal of Infrastructure Systems, Vol. 12 No. 2, pp. 69-76.
[21] What future for rural tourism in Romania? The courier: Issue NR. IV (N.S.) - January/February 2008. 